\title{
THE CIRCULATORY BEHAVIOUR IN COMPLETE CHRONIC PARAPLEGIA
}

\author{
By Y. Bidart and M. MaURY 1 \\ Centre de Rééducation Motrice de Fountainebleau (Caisse Régionale d'Assurance \\ Maladie de Paris) and Unité d'Enseignement et de Recherches Paris-Saint-Pères \\ -Département de Physiologie.
}

DURING World War II the systematic study of the circulatory problems in paraplegia was began by Sir Ludwig Guttmann and continued after the war by him and his colleagues at Stoke Mandeville.

The loss of thermoregulatory vasomotor adaptation (Cooper et al., 1957; Guttmann et al., 1958) and the cardiovascular responses to bladder distension (Guttmann \& Whitteridge, I947; Cunningham et al., I953), were the main results of the first studies.

In the following years, studies were made on the behaviour of denervated vessels (after peripheric nerves section or after sympathectomy) during responses to cold (Shepherd \& Thompson, I953), heat (Duff, I951; Duff \& Shepherd, 1953) ischaemia (Folkow, 1960, Shepherd, 1964) and local muscular exercise (Haddy \& Scott, I968).

Galibert (1958, 196I) and Benassy et al. (1960) found in some cases of spinal cord injury and increase in blood flow in the lower limbs.

In I965, Silver, while studying tetraplegic patients, showed the loss of vasomotor adjustments to changes of the repartition of blood volume and to heat.

A co-operative work has been carried out in the past few years by the Garches School (under the direction of Prof. Grossiord) and the Department of Physiology of the Faculté de Medecine de Paris (Prof. Durand, Prof. Martineaud) in order to study the responses of the resistance and capacitance vessels (Seroussi et al., 1967; Jaeger-Denavit et al., I969) to local temperature.

The correlations between the cardiovascular troubles and their hormonal consequences were studied by Guttmann et al. (1963), Claus-Walker et al. (1969) and recently by Johnson et al. (I97I) who have clearly demonstrated the hormonal compensations to vasomotor insufficiencies.

With the help of the many previous works, a systematic study of the infralesional circulation in paraplegic patients and its response to local and general stimuli, was begun in 1968 at the Centre de Rééducation Motrice de Fountainebleau.

All patients studied were males, I5-45 years old, with no accompanying illness which would affect the lower limb circulation. The paraplegia was clinically complete for at least 9 months. The segmental level of the lesion will be indicated in each programme.

It is attempted to systematise the particular circulatory comportment after a medullar transection by using the results of this study.

\section{The Infralesional Circulation is nOt Regulated}

(a) A general observation may be made about the results of all studies: there are great differences between the circulatory data measured in paraplegics having

${ }_{1}$ This work was supported by a financial help from the Communauté Européenne du charbon et de l'Acier.

I I I I A 
the same lesion, or even between the data measured on the same patient with an interval of several days. In statistical terms, the standard deviation of the paraplegics circulatory data is much greater than in control subjects.

(b) The loss of central regulation makes the cutaneous circulation abnormally dependent upon local conditions. This is clearly depicted by a comparison of cutaneous blood flow measured at different temperatures in paraplegics and control subjects (fig. I).

The cutaneous blood flow was measured at every degree (Celsius) from $6^{\circ} \mathrm{C}$. to $40^{\circ} \mathrm{C}$ with regular water plethysmograph method in 23 normal subjects (healthy males $20-40^{\circ}$ years old) and 22 paraplegics with a medullar lesion above $\mathrm{T}^{\circ} 9$. The room temperature was $23^{\circ} \mathrm{C}$. \pm I and for 30 minutes before study commenced the subject was in the supine position.

The main characteristic of the blood flow in the control subjects is its constancy
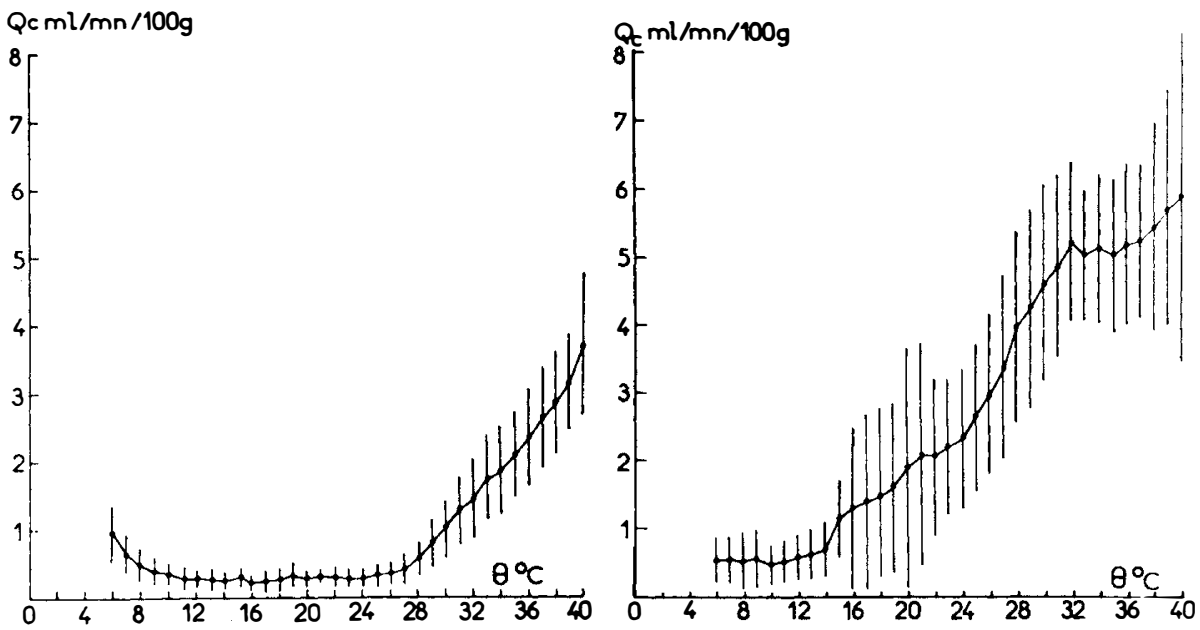

FIG. I

Cutaneous blood flow as function of skin temperature. Ordinate: skin blood flow $\mathbf{I} \pm$ S.D.

Abscissa: skin temperature. Left: control subjects. Right: paraplegics.

in the range of temperature between $10^{\circ} \mathrm{C}$. and $27^{\circ} \mathrm{C}$. with an increase in the extremes. On the other hand, the variations in paraplegics of cutaneous blood flow caused by the variation of local temperature is approximately linear (the same linear variation was shown by Jaeger-Denavit et al., 1969).

As linear variation is a characteristic of physical influence rather than physiological regulation, its significance may be accepted as the dependance of blood flow to local conditions rather than general haemodynamic or thermic needs.

\section{Circulatory Adjustments to Local Metabolic Needs}

(a) Cutaneous Circulation. The adjustment of cutaneous circulation to local metabolic needs was studied by measuring the cutaneous blood flow before and after a temporary arrest of the circulation to the foot by means of a tourniquet. 
Method. The cutaneous blood flow was measured in the foot with the water plethysmography. Two series of experiences were performed with two different water temperatures: $16^{\circ} \mathrm{C}$. and $33^{\circ} \mathrm{C}$. The room temperature was $22^{\circ} \mathrm{C} . \pm \mathrm{I}$. A pneumatic cuff was inflated at the ankle with a pressure of $300 \mathrm{~mm}$. $\mathrm{Hg}$. for Io minutes, after registration of the blood flow.

After release of the tourniquet, the foot blood flow was repeatedly measured for 6 minutes.
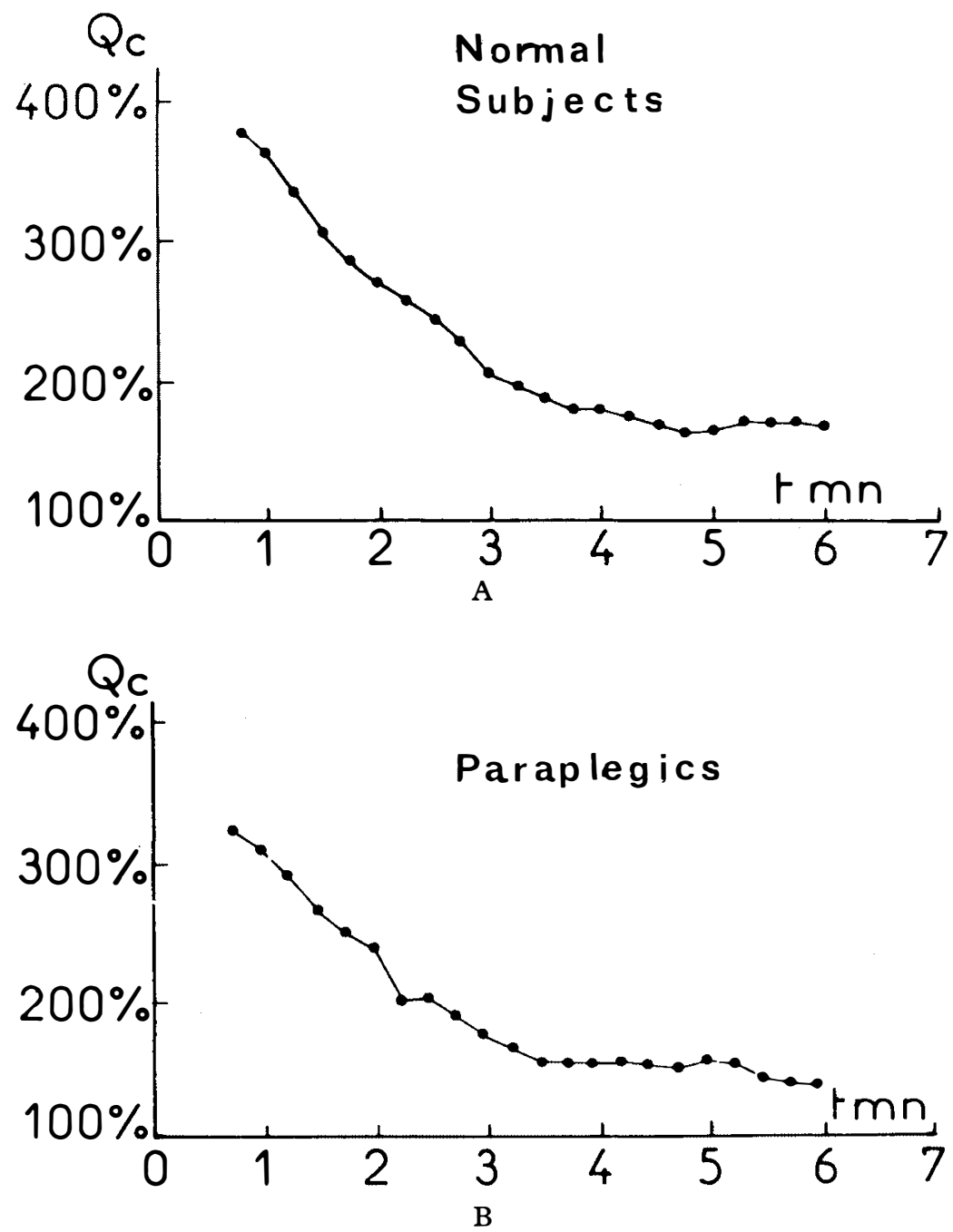

FIG. 2

Changes of cutaneous blood flow after a temporary arrest of the foot circulation. Ordinate: cutaneous blood flow (percentage of the preischaemia value). Abscissa: time after release of the tourniquet. A, Normal Subjects. B, Paraplegics. 
A comparative study was performed on ten control subjects (males 20-40 years old) and 16 paraplegics with a complete medullar transection above $\mathrm{T}_{7}$.

Results. The response of the cutaneous circulation was the same for both the paraplegics and the controls at the two temperatures. A I0-minute ischaemia caused an important increase in blood flow and the return to basal value had the same constant time (fig. 2)

It can be concluded from this that, in paraplegics, the cutaneous circulatory adjustments to local metabolic needs are normal.

\section{(b) Muscular Circulation}

The adjustments of muscular circulation to local metabolic needs were studied with two techniques: the measure of muscle blood flow and the measure of femoral venous blood gases.

\section{(I) Measuring of Muscle Blood Flow}

The I33 Xenon local clearance technique (Lassen et al., 1964) was used (figs. 3, 4).

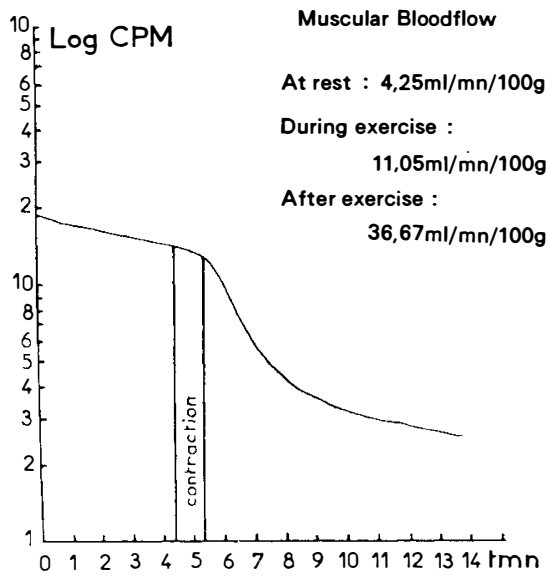

FIG. 3

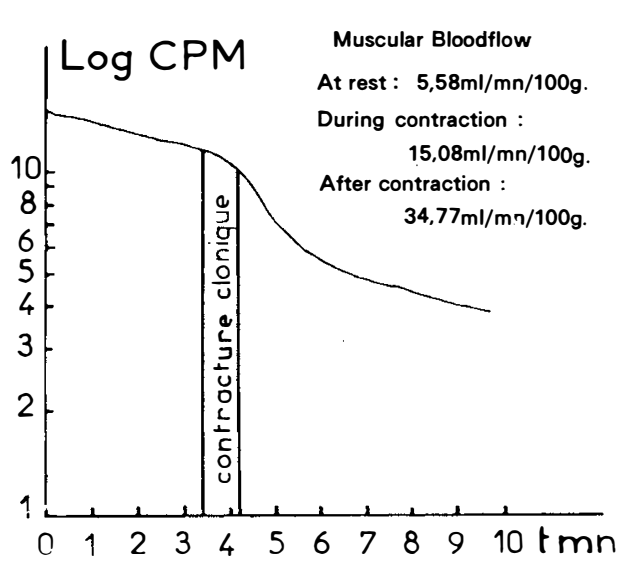

FIG. 4

Fig. 3.-Normal subject: measure of the muscular blood flow by the study of the local radioactivity after injection of $\mathrm{I} 33$-Xenon into the gastrocnemius. At rest: $4 \cdot 25 \mathrm{ml} / \mathrm{mn}$./ $100 \mathrm{~g}$. During exercise. Ordinate: logarithm of activity. Abscissa: time. The slope is a function of local muscular blood flow.

Fig. 4.-Paraplegic patient: measure of the muscular blood flow (same technique). At rest: $5.58 \mathrm{ml} . / \mathrm{mn}$./100 g. During contraction: $15.08 \mathrm{ml} / \mathrm{mn}$./100 g. After contraction: 34.77 $\mathrm{ml} . / \mathrm{mn} . / \mathrm{IOO} \mathrm{g}$.

The blood flow was measured in the gastrocnemius at rest, during contraction and after contraction.

In nine paraplegics with a medullar transection above $\mathrm{T} 9$, reflex contractions were induced by stretching the gastrocnemius. In seven normal subjects, the contractions were voluntary. 
Results. Normal subjects:

Resting blood flow $\quad 2.64 \mathrm{ml} . / \mathrm{mn} . / \mathrm{I} 00 \mathrm{~g} . \pm \mathrm{I} \cdot 26$

Contraction blood flow: $3 \mathrm{I} \cdot 34 \mathrm{ml} / \mathrm{mn} . / 100 \mathrm{~g} \cdot \pm 20 \cdot 04$

Paraplegics:

Resting blood flow : $2 \cdot 34 \mathrm{ml} . / \mathrm{mn}$./100 g. $\pm \mathrm{I} \cdot 42$

Contraction blood flow: $18.65 \mathrm{ml} . / \mathrm{mn} . / 100 \mathrm{~g} . \pm 13.40$

Blood flow at contraction cannot be quantitatively compared because the spasmodic reflex contractions obtained by hand in paraplegics cannot be regulated or measured. Thus, the contraction power and metabolic needs cannot be equally maintained in all subjects.

So, it can only be concluded that in paraplegics, as in normals, the muscular contractions induce a similarly large increase in muscle blood flow.

\section{(2) Measuring of Femoral Venous Blood Gases}

In order to study the second mechanism used for the increase of respiratory exchanges during muscular contraction i.e. the increase in gases arteriovenous difference, samples of femoral venous blood were taken at rest and at the 30th second of muscular contractions of the whole lower limb.

\section{TABLE I}

Changes in gas content of the femoral venous blood during contractions of the lower limb.

\begin{tabular}{|c|c|c|c|}
\hline & Rest & $\begin{array}{c}\text { 3oth second } \\
\text { contractions }\end{array}$ \\
\hline $\begin{array}{r}\mathrm{S}_{\mathrm{O}_{2}} \\
\mathrm{p} \mathrm{IOO}\end{array}$ & Paraplegics & $7 \mathrm{I} \cdot 7 \pm \mathrm{II} \cdot 7$ & $67 \cdot 0 \pm \mathrm{I0} \cdot 2$ \\
\hline $\begin{array}{c}\mathrm{P}_{\mathrm{CO}_{2}} \\
\mathrm{~mm} . \mathrm{Hg}\end{array}$ & Normals & $46 \cdot 6 \pm 3.9$ & $49 \cdot \mathrm{I} \pm 3.7$ \\
\hline
\end{tabular}

In I I paraplegics with a medullar transection above T9 a strong and protracted mass reflex was provoked by nociceptive stimulus of the foot. In seven normal subjects, voluntary contractions simulated the spasmodic contractions of the paraplegics. The oxygen saturation was measured by a haemoreflectour of Kipp and the $\mathrm{P}_{\mathrm{CO}_{2}}$ was measured with a Radiometer electrode.

Comments. The femoral venous blood is not only representative of the muscular circulation because part of it comes from other tissues, skin, bone, etc. 
However, the metabolism of these other tissues does not change during the 30second contractions. Thus, the above changes can be accepted as resulting from the muscular metabolism increase.

Conclusion for the Study of Muscular Circulation. In paraplegics, the adjustments to an increase in metabolic needs are the same as in normals: increase in muscle blood flow and increase in arteriovenous gases difference.

Conclusion for the Study of the Circulatory Adjustments to Local Metabolic Needs. In the infralesional vascular area of paraplegics, the circulatory adjustments to local metabolic needs are normal. Consequently, they do not seem to be dependent upon the supramedullar nervous centres. This conclusion is in agreement with other studies on denervated limbs (Shepherd, I964), and isolated muscles (Duff, I95I; Haddy \& Scott, I968).

\section{The Loss of the Local Vascular Responses to Cold}

In normal man, cold exposure of limbs' extremities induces an increase in local cutaneous blood flow and thus an increase in local temperature (Greenfield, 1954). The increase in local blood flow is caused by the opening of arteriovenous anastomoses.

This vascular adjustment to local thermic needs was comparatively studied in five normal subjects and in seven paraplegics with a complete medullar transection above Tro.

Methods. The blood flow was measured at the foot with a regular water plethysmograph.

Room temperature was $23^{\circ} \mathrm{C} . \pm \mathrm{I}$.

After a 30 minutes rest in a supine position, the foot blood flow was first measured at the local temperature of $16^{\circ} \mathrm{C}$. (temperature for the minimum cutaneous blood flow in normal man). Then the plethysmograph water was changed to cold: $6^{\circ} \mathrm{C}$. After 10 minutes, the blood flow was measured every minute, for Io minutes and the mean blood flow was calculated.

In four paraplegics, the foot blood flow was measured at the local temperature of $16^{\circ} \mathrm{C}$. while the other foot was exposed to a temperature of $6^{\circ} \mathrm{C}$.

Results. In normal subjects, cold exposure increased the foot blood flow:

$$
6^{\circ} \mathrm{C} \text {. blood flow }=16^{\circ} \mathrm{C} \text {. blood flow } \times 3.45 \pm 1 \cdot 89
$$

In paraplegics there was a decrease:

$$
6^{\circ} \mathrm{C} \text {. blood flow }=16^{\circ} \mathrm{C} \text {. blood flow } \times 0.60 \pm 0.26
$$

The decrease in blood flow during cold exposure was not due to an autonomic hyper-reflexia: this was evident after the measure was taken at $16^{\circ} \mathrm{C}$. while the other foot was exposed to $6^{\circ} \mathrm{C}$.:

$16^{\circ} \mathrm{C}$. blood flow (other foot at $6^{\circ} \mathrm{C}$.) $=16^{\circ} \mathrm{C}$. blood flow $\times 0.96 \pm 0.30$ 
Conclusion. After a medullar transection at the thoracic level, the local vasomotor adjustment to local cold exposure (hunting phenomenon) is abolished in the feet.

This observation allows us to say that its command is not a histamine-like substance locally released during exposure of the cutaneous tissue to cold, or axon reflex, or a medullar reflex. A supramedullar nervous control seems necessary for the local vascular adjustment to local exposures to cold.

\section{The Loss of Vasomotor Adjustments to General NeEds}

\section{(a) Vasomotor Adjustments to Heat}

This problem has been studied by Cooper et al. (1957) but in our systematic study we had to reproduce it.

Method. A comparative study was performed on four normal subjects (healthy males 25-35 years old) and eight paraplegics (male 20-40 years old) with a complete medullar transection above $\mathrm{T} 9$.

The foot blood flow was measured with the water plethysmograph;

The room temperature was $22^{\circ} \mathrm{C} . \pm \mathrm{I}$ and the water temperature was $25^{\circ} \mathrm{C}$.

After a 30 minute rest in the supine position, the foot blood flow was repeatedly measured. After this measure, the upper part of the subject (thorax, upper limbs and head) was wrapped in a heating blanket for 15 minutes. The foot blood flow was measured again.

Results. In the normal subjects, the general exposure to heat provoked a considerable increase in foot blood flow:

$$
\text { heat blood flow }=22^{\circ} \mathrm{C} \text {. blood flow } \times 3.30
$$

In the paraplegics, there was a slight decrease in the foot blood flow:

$$
\text { heat blood flow }=22^{\circ} \mathrm{C} \text {. blood flow } \times 0.88
$$

Comments. The changes in foot blood flow can be accepted as changes in cutaneous blood flow because skin is the main component of the foot volume and it is practically the only component where blood flow can change quickly.

In normal subjects, changes in cutaneous blood flow are local adjustments to general thermic exchanges.

In paraplegics, the infralesional vascular area is unable to play in adaptation to general thermic needs.

This fact was suggested by the comparison of the curves of foot blood flow as function of local temperature in paraplegics and normals (fig. I): in paraplegics, the cutaneous blood flow is passively dependent upon the local temperature and the curve is approximately linear, while in normal subjects, in a range of local temperature between $10^{\circ} \mathrm{C}$. and $27^{\circ} \mathrm{C}$., the blood flow is independent from the local temperature and depends upon the general needs of thermic exchanges.

This loss of cutaneous circulatory adjustments to general thermic needs is a part of the thermoregulatory deficit of the paraplegics: the greater the nervous control deprived skin area, the greater is this thermoregulatory deficit. Other 
recent works (Miller et al., I969; Johnson, I97I) have concluded similar results for the reaction to cold and for heat production (shivering).

\section{(b) Cutaneous Vasomotor Adjustments to Muscular Exercise}

The cutaneous vascular adjustments at the beginning of muscular exercise have been studied by many investigators in recent years. These studies have shown that the important increase in blood flow in exercising muscles requires a corresponding increase in cardiac output and a preferential repartition of blood flow to these muscles.

The immediate increase in cardiac output needs an immediate increase in venous return. This is obtained by a general venoconstriction at the beginning of muscular exercise (Bevegard and Shepherd, 1965; Folkow \& Melinder, 1964; Martineaud et al., 1970).

The preferential repartition of blood flow to exercising muscles is realised by a reduction in blood flow in the resting areas. So, the cutaneous blood flow is reduced at the beginning of muscular exercise (Seroussi et al., 1969).

After medullar transection, interruption of the nervous control of the lower limb vessels may be expected to deprive the patient of these adaptative vascular adjustments.

\section{Material and Methods}

\section{STUDY OF THE VENOMOTRICITY}

The studied venous area was the foot.

The room temperature was controlled at $22 \cdot 5^{\circ} \pm 0 \cdot 5^{\circ} \mathrm{C}$.

The experiments were performed on 17 control subjects (healthy males 20-40 years old) and I 5 paraplegics (males I 5-45 years old without cardiovascular disease). The spinal cord lesion in seven of the paraplegics was located between $\mathrm{T}_{4}$ and $\mathrm{T} 6$, in five others between $\mathrm{T}_{7}$ and $\mathrm{T}_{9}$ and in the three others between $\mathrm{T}_{\mathrm{O}} \mathrm{O}$ and Tr2. These spinal cord lesions had been clinically complete for one to three years.

Venous tone changes in these 32 subjects were studied during and after a muscular exercise performed with the upper limbs in the supine position for I minute, with a power of 50 watts.

Techniques. Two techniques were simultaneously performed, one in each foot:

\section{Measure of Venous Pressure at Constant Volume (fig. 5)}

This method was described by Wallace in 1956 and was used by other investigators (Bevegard \& Shepherd, I965, Samueloff et al., I966).

The venous pressure was measured directly with a needle inserted into the internal saphenous vein at the ankle. After having recorded the basal venous pressure, a pneumatic cuff was placed around the calf and inflated to $30 \mathrm{~mm}$. $\mathrm{Hg}$ in order to increase the blood volume in the studied vascular area and thus increasing the vasomotor effects. The cuff was then inflated to $350-400 \mathrm{~mm}$. Hg of pressure to insulate the distal vascular area from the general circulation. This resulted in an increase of the venous pressure by moving blood from the compressed calf to the foot. In this insulated vascular territory, the blood volume remains essentially in the veins, and the pressure is dependent on the venous tone. For the 
first few minutes, the venous tone is regulated only by the nervous control. Thus, the changes in venous pressure will express the changes in nervous control.

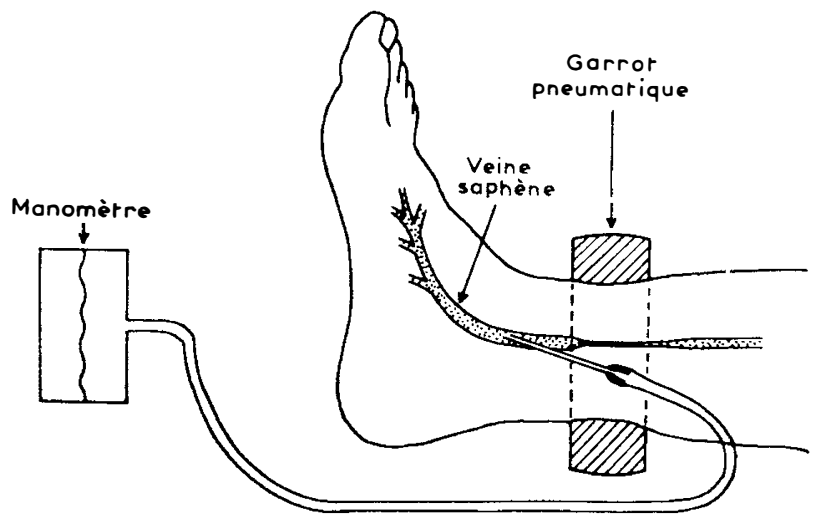

FIG. 5

Venous pressure measurement at constant volume.

\section{Study of THE Foot Blood Volume}

The changes of foot volume were simultaneously recorded on the other foot by a regular plethysmograph.

The changes were accepted as changes in distal blood volume.

The water temperature was $33^{\circ} \mathrm{C}$.

An unfortunate inconvenience of muscular exercise was that it involved the whole body, producing artifacts on the volume recording which made it hardly reliable.

\section{Results}

At Rest. The basal venous pressure was the same in the two groups of subjects:

Before insulation: $15 \cdot 39 \pm 2.60 \mathrm{~mm}$. Hg

After insulation: $45.90 \pm 13.50 \mathrm{~mm}$. $\mathrm{Hg}$

At Exercise. In control subjects (fig. 6): the venous tone increased at the beginning of exercise, remained high IO-I 5 seconds after exercise was stopped and then decreased. For I minute of a 50 watts exercise, the mean changes were:

$$
\begin{aligned}
& \Delta \mathrm{Pv}=8.5 \pm 4.9 \mathrm{~mm} . \mathrm{Hg} \\
& \Delta \mathrm{V}==6.5 \pm 3.3 \mathrm{ml} . / \text { foot. }
\end{aligned}
$$

In paraplegics: in the case of a high spinal cord lesion (above $\mathrm{T}_{7}$ ), there was no change in venous tone: insulated venous pressure and foot volume remained constant during exercise (fig. 7).

In the case of a spinal cord lesion below Tro, the venous tone increased as in control subjects.

In case of spinal cord lesion between cord between $\mathrm{T}_{7}$ and $\mathrm{T}_{\mathrm{I}} \mathrm{O}$, the changes of venous tone were irregular. 


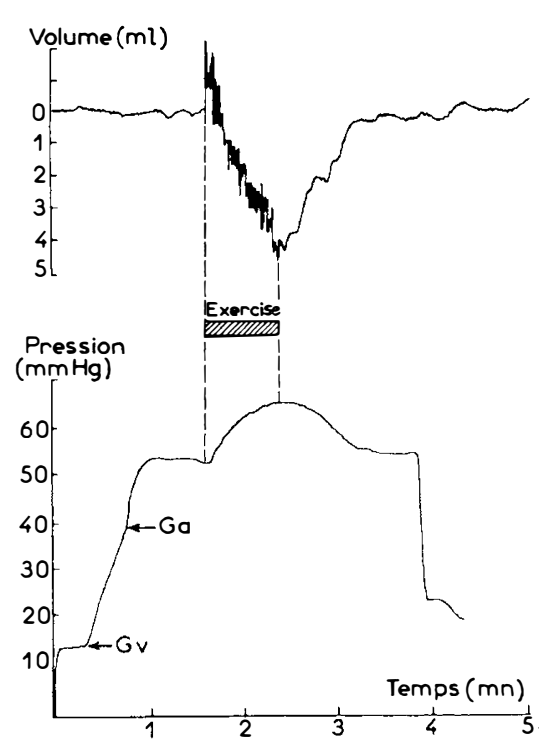

FIG. 6

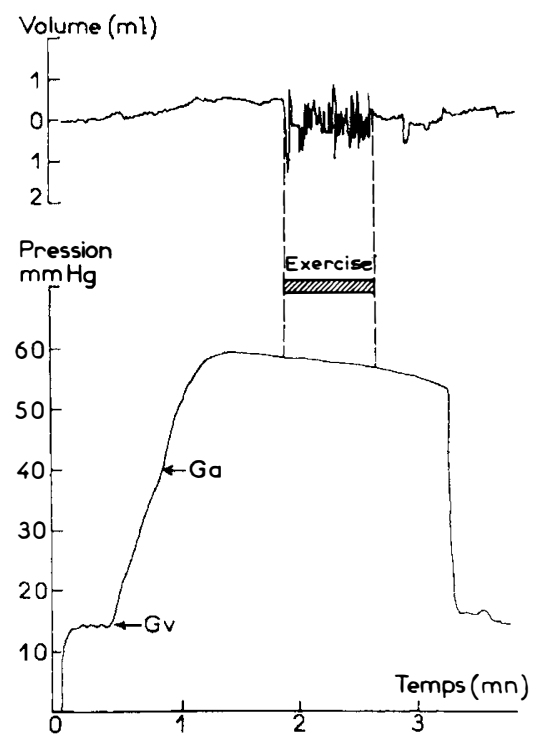

FIG. 7

Fig. 6.-Control subject: changes in venous tone of the foot at the beginning of muscular exercise of the upper limbs. Upper graph: plethysmographic recording of the foot volume. Lower graph: recording of the venous pressure at constant volume. Gv: venous cuff ( $30 \mathrm{~mm}$. $\mathrm{Hg}$ ). Ga: arterial cuff $(350 \mathrm{~mm} . \mathrm{Hg})$.

Fig. 7.-Paraplegic subject: lack of change in venous tone during the same muscular exercise (same technique as fig. 6).

\section{STUDY OF ARTERIOLAR MOTRICITY}

Material and Methods. Measures were made on nine control subjects (healthy males 20-40 years old) and I4 paraplegics (males I5-40 years old without cardiovascular disease).

The blood flow was measured at the foot by the strain-gauge plethysmograph as described by Whitney (1953). As it is impossible to calculate peripheral blood flow accurately from the strain-gauge plethysmograph data, changes in blood flow have only been expressed in percentage of basal value, before exercise, the absolute flow remained unknown.

The muscular exercise was the same as for the study of venomotricity but lasted for 4 minutes.

The room temperature was $22.5^{\circ} \pm 0.5^{\circ} \mathrm{C}$.

Results (fig. 8). In the control subjects, as soon as exercise was proposed, the foot blood flow was considerably reduced to as low as 20 per cent. of the resting value. This purely psychologic phenomenon was able to maintain a low blood flow in the foot for 2 minutes. When, at last, the muscular exercise was actually performed, the foot blood flow first decreased slightly further, and then during the 4 minutes of exercise increased slowly. By the end of exercise, the foot blood flow had reached a higher value than before exercise (this secondary increase of skin 
blood flow is interpreted as a thermoregulator phenomenon). These results are similar to those published by Seroussi et al. (I969).

In paraplegics, the foot blood flow is not modified by the psychologic preparation for exercise. The significance of the increase in blood flow noted during exercise will be discussed. After exercise, the flow falls back to resting value.
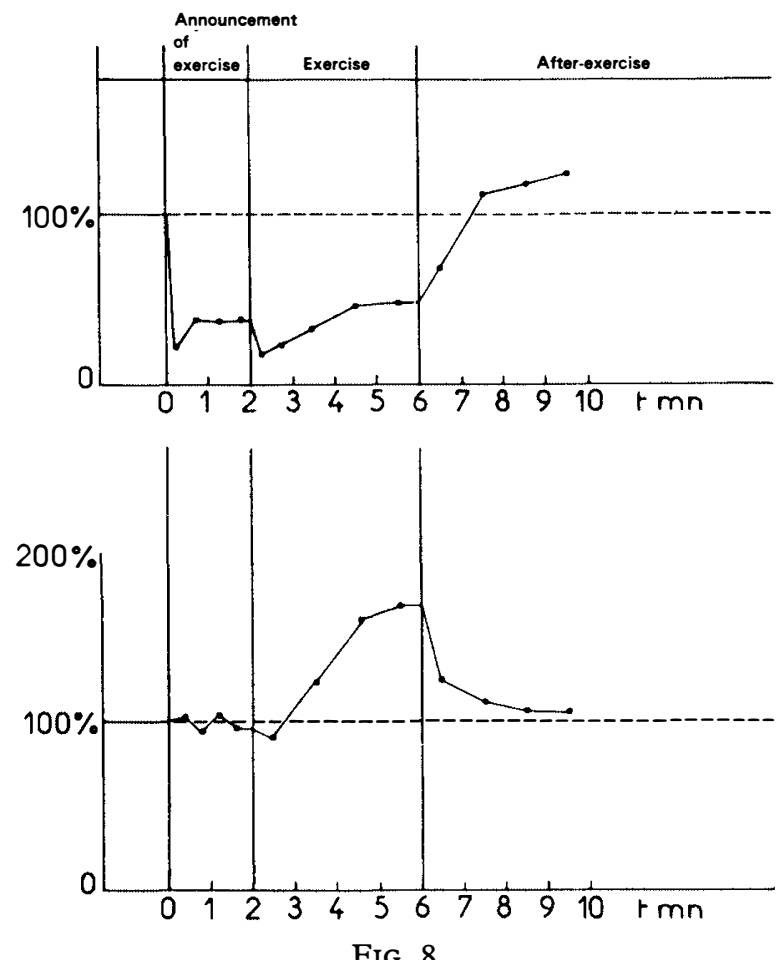

Changes in foot blood flow during proposed exercise (annonce de l'exercice), exercise of the upper limbs (exercice) and post-exercise. Upper graph: control subjects. Lower graph: paraplegics.

\section{COMMENTS}

I. Nervous Command of Venoconstriction. The circulatory insulation of the studied venous area allows us to say that a humoral factor is not responsible for the venoconstriction (the effectiveness of the circulatory insulation has been verified by infusion of nor-epinephrin into general circulation: there was no vascular change in the insulated segment while the arterial blood pressure had been doubled).

Neither is a local mechanism such as involuntary muscle contraction responsible for the vascular change. This has been verified in a paraplegic patient with frequent spasmodic contractions in the lower limbs. Each muscular contraction caused a sudden and brief pressure increase in the insulated venous territory, very different from the slow increase observed in normal subjects during exercise (fig. 9).

The venoconstriction during exercise is not the result of the proprioceptive 


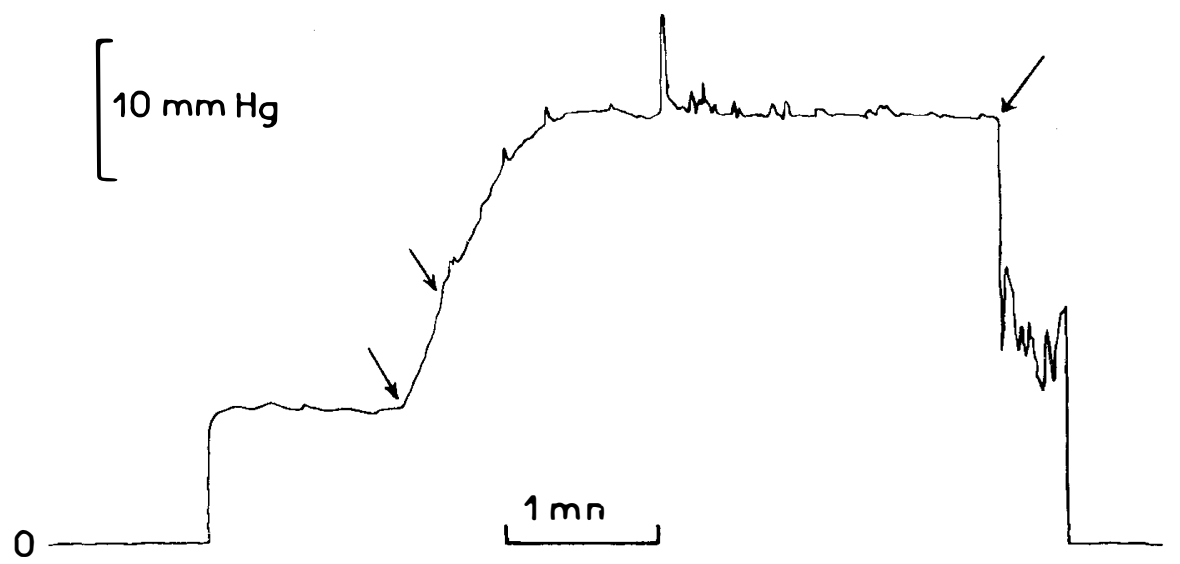

FIG. 9

Paraplegic subject: involuntary muscle contractions have no vasomotor action (venous pressure at constant volume: Ist arrow: venous cuff, 2nd arrow: arterial cuff, 3 rd arrow release of the arterial cuff).

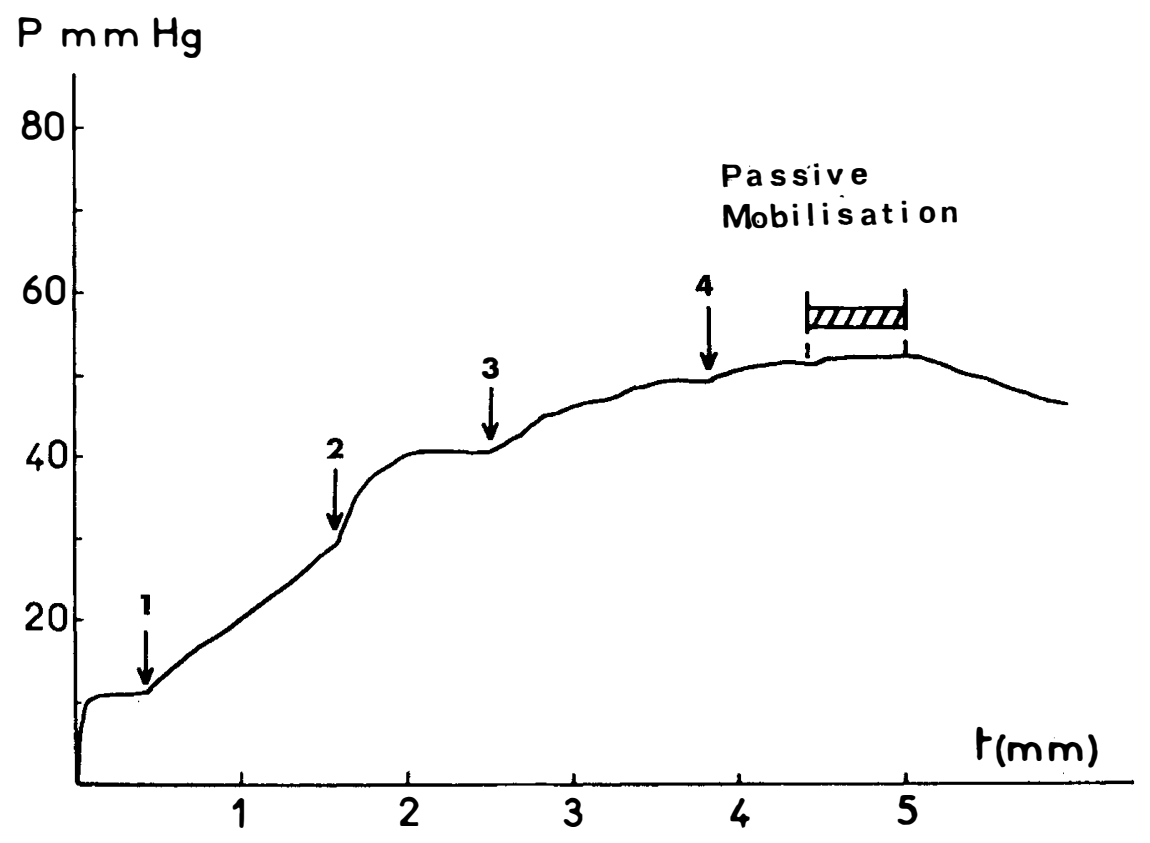

Fig. IO

Control subject: the passive mobilisation of the upper limbs (proprioceptive reflex) has no vascular action on the foot ( $\mathrm{I}$ : venous cuff, 2 : arterial cuff, 3 : the subject is told that passive mobilisation will be performed, 4 : the subject's hands are placed in the operator's hands). 
reflex initiated in the exercising limbs. This has been shown by passive mobilisation of the upper limbs of normal subjects; if the psychologic side-effects are eliminated, no venoconstriction occurs in the feet (fig. IO).

Since cutaneous venoconstriction during exercise is not commanded by a humoral factor, local mechanism or a proprioceptive reflex, and it is abolished by a spinal lesion, we can conclude that it is dependent on a nervous supply of supramedullar origin.

2. Nervous Command of Arteriolar Constriction. The changes in cutaneous blood flow during exercise are more difficult to understand. Why does it increase in paraplegics?

In some cases, it seems clear. The arterial pressure increases during exercise and we can expect that, if the arterial tone does not increase, the blood flow will be higher.

In some other cases, although there was no increase or decrease in the arterial pressure, the increase in cutaneous blood flow was the same.

Only one thing is clear: if the spinal cord is cut, the cutaneous blood flow increases during exercise in the denervated segment while it decreases in those segments where nerve supply is intact. The psychologic association to exercise seems to be important in this phenomenon.

3. Quantitative Estimation. The quantitative estimation of these cutaneous vasomotor adjustments seems difficult:

Venoconstriction. The water plethysmograph has given many volume change data but these data cannot be trusted. The contact between the ankle and the plethysmograph is assured by a rubber cuff and hydrofuge paste. This causes a resistance to venous flow and then an increase in foot blood volume. Under these conditions, increase in venous tone will cause a greater change of foot blood volume than would occur in a free foot. The volume changes measured by water plethysmograph are then overestimated.

Furthermore, the volume changes in the foot cannot be honestly extrapolated to the whole skin surface whose vasomotor comportment is very probably irregular.

An attempt was made to measure segment by segment the volume changes of the limbs during exercise (with strain-gauge) by measuring the changes of girth at several levels, and, after geometric calculation, deducing the volume changes. The results fluctuated and seemed to be very dependent on the initial blood volume in the studied segment. This blood volume is first of all dependent on the venous pressure and then on the location in relation to the hydrostatic indifferent point. Once more, the data obtained in one segment could not be extrapolated to other segments in other positions.

Thus, methods for the study of local peripheral blood volume cannot be used to know the general cutaneous blood volume changes.

Arteriolar Constriction and Reduction of Skin Blood Flow. The strain-gauge plethysmograph method used during the present work cannot give absolute values of blood flow. But the other methods for measure of skin blood flow are inconvenient for this study of a brief exercise. Therefore, we could not obtain a more quantitative estimation than a reference to resting blood flow.

Once more, the data obtained in the foot cannot be extrapolated to the whole 
skin surface. Finally, we can consider it impossible to measure quantitatively by peripheral methods the changes of cutaneous blood volume and blood flow occurring at the beginning of a muscular exercise.

Conclusion. The results obtained during the present work confirm that the peripheral vascular adjustments at the beginning of exercise are initiated by a
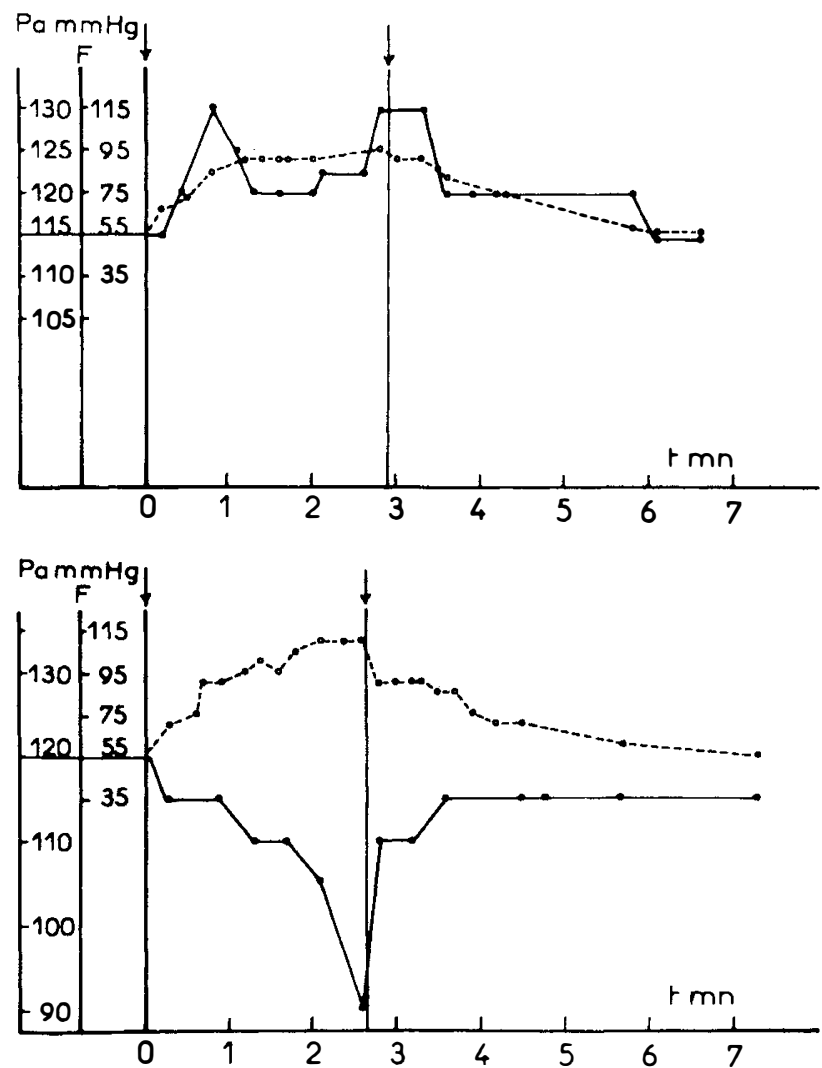

FIG. II

Paraplegic subject (segmental level T3): comparison of the general cardiovascular changes: during exercise with (upper graph) and without (lower graph) abdominal elastic girth. $\mathrm{Pa} \mathrm{mm}$. Hg: systolic arterial blood pressure measured at the foot (plain line). F: heart rate (broken line). Between the two arrows: 50 watts muscular exercise.

nervous command of supramedullar origin. This nervous command is activated simultaneously with the muscular command.

In paraplegic patients, the interruption of this nervous command causes the loss of the cutaneous vascular adjustments at exercise. The consequences of this loss are:

A delay before the increase in cardiac output (absence of venoconstriction). A squandering of cardiac output in inactive areas. 
These two consequences, if the medullar transection is high, may cause a deficit in cardiovascular adaptation to exercise, because the denervated cutaneous area is large, and furthermore, the splanchnic area may be denervated too. In these cases, it was often noted that an attempt for hard muscular exercise was stopped by fainting with a decrease of arterial blood pressure.

To reduce this haemodynamic handicap, mechanical means can be helpful in preventing the pooling of blood in inactive areas: abdominal elastic girth and elastic stocking. In some patients, we could ascertain the efficiency of these materials: with the help of the bindings a strenuous muscular exercise was easily performed (with an increase in arterial blood pressure), while a fall in arterial blood pressure previously prevented strenuous exercise (fig. II).

\section{(c) Cutaneous Vasomotor Adjustments to Tilting}

The postural hypotension of paraplegics is a well known problem. It is generally accepted as a result of the loss of vasomotor adaptation to tilting.

\section{Study of Venous Tone in the Lower Limbs During Tilting}

Material and Methods. The venous compliance was studied in five paraplegics with a medullar transection above $\mathrm{T} 9$.

The technique was the study of volume changes at the foot in relation with changes in venous pressure. The changes of volume were measured with the strain-gauge plethysmograph (Whitney, 1953). The changes of venous pressure were obtained with a pneumatic cuff around the ankle, inflated at increasing pressures from Io to $100 \mathrm{~mm}$. Hg. The cuff was deflated between each measure in order to avoid secondary modifications of the venous distensibility.

From these datas, compliance curves were established in the supine position and then with a $30^{\circ}$ head-up tilt (the angle of $30^{\circ}$ was not surpassed in order to avoid the perturbation of contention means. At this angle the pressure stimulus is half of the complete tilting stimulus.).

Results (fig. 12). The compliance curves can be compared only above the pressure of $50 \mathrm{~mm}$. Hg because the $30^{\circ}$ tilting increases the blood pressure to this number and it was impossible to establish the curves at a lower pressure during tilting.

It can be seen that the venous tone is the same in supine position and during tilting.

The result of this loss of venomotor adjustment may be a pooling of blood in the lower part of the body with the increase in hydrostatic pressure.

\section{Extra-Vascular Influences upon the Lower Vessels}

The loss of vasomotor adjustments is not the only factor responsible for postural hypotension: any venous return insufficiency may decrease the cardiac output and consequently the arterial blood pressure.

In normal subjects, an important factor for the venous return in the upright position is the 'peripheral muscle pump', i.e. compression of the lower limb veins by muscular contractions. 
In case of flaccid paraplegia, the muscle pump is, of course, inactive and the pooling of blood in the lower limbs may be increased.

A study was done in spasmodic paraplegics to estimate the efficiency of involuntary contractions and to measure the pooled blood volume in the legs.

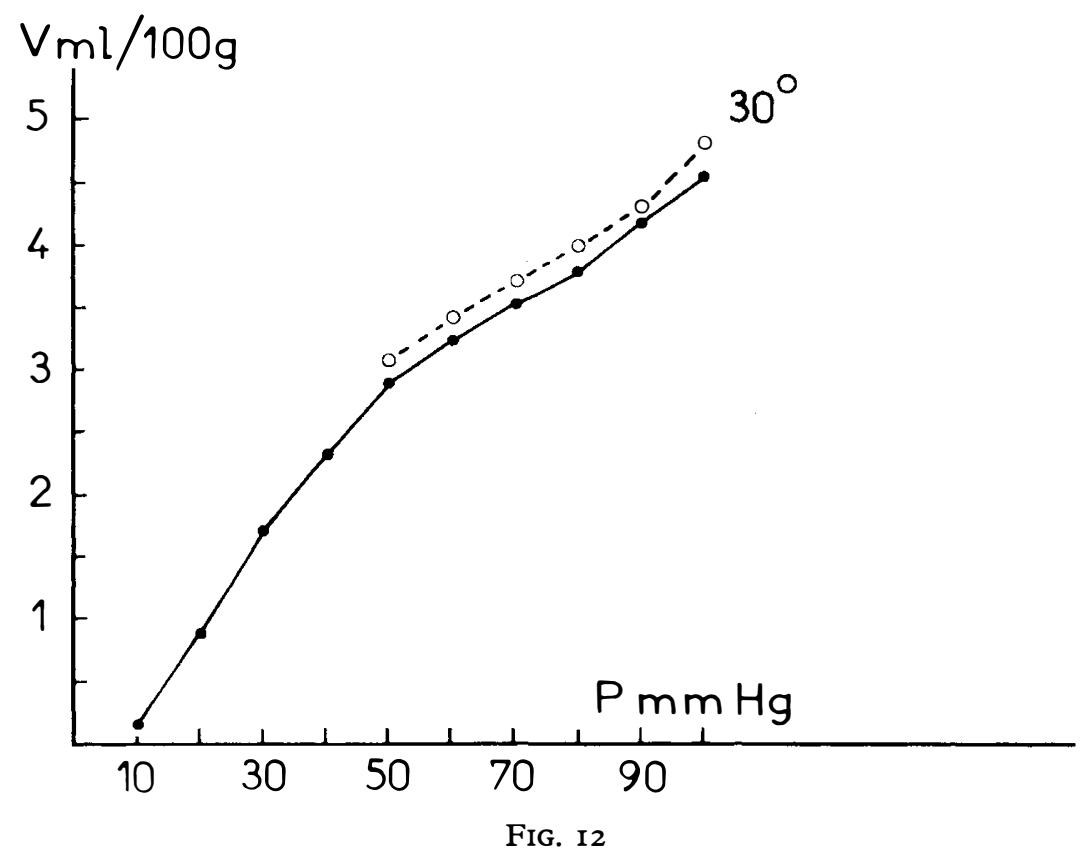

Comparison of the compliance curves of the foot veins in the supine position (decubitus) and during a $30^{\circ}$ head-up tilt ( $30^{\circ}$ inclination). Mean values from five paraplegics.

Methods. The venous blood pressure was continuously registered in the internal saphenous vein in the ankle, by a needle connected with a manometer (ACB 440 hd) and a potentiometric recorder (Cimapot DBZ). After having registered the pressure in the supine position, the subject was tilted to a $45^{\circ}$ angle. In all cases, the tilting caused an increase in venous pressure, until $60-70 \mathrm{~mm}$. $\mathrm{Hg}$ (the pressure corresponding to the hydrostatic pressure at the bottom of the blood column extending from the hydrostatic indifferent point to the studied level).

In these conditions, the efficiency of the peripheral muscle pump was compared between five control subjects and eight spasmodic paraplegics. While the venous pressure was continuously registered, the control subjects made gastrocnemius voluntary contractions against a resistance, and in spasmodic paraplegics, involuntary contractions were obtained by myotatic reflex in the gastrocnemius muscle of the dependent leg.

Results. In both cases (figs. I3-I4) the result was similar: a brief pressure increase during the muscle contraction followed by an important decrease during 


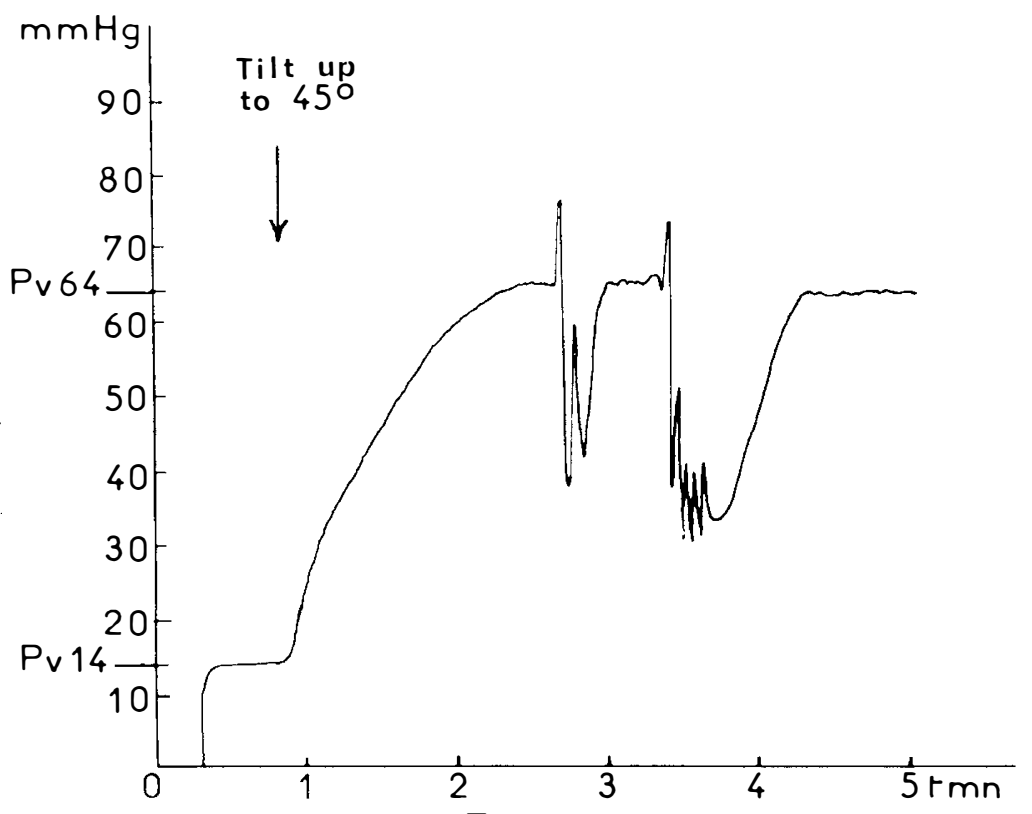

FIG. I3

Control subject: effect of gastrocnemius contraction on the venous pressure at the foot. Ordinate: pressure in the internal saphenous vein. Pv $14 \mathrm{~mm}$. Hg: pressure in the supine position; Pv $64 \mathrm{~mm}$. Hg: pressure after a $45^{\circ}$ head-up tilt. Effect of 2 series of contractions.

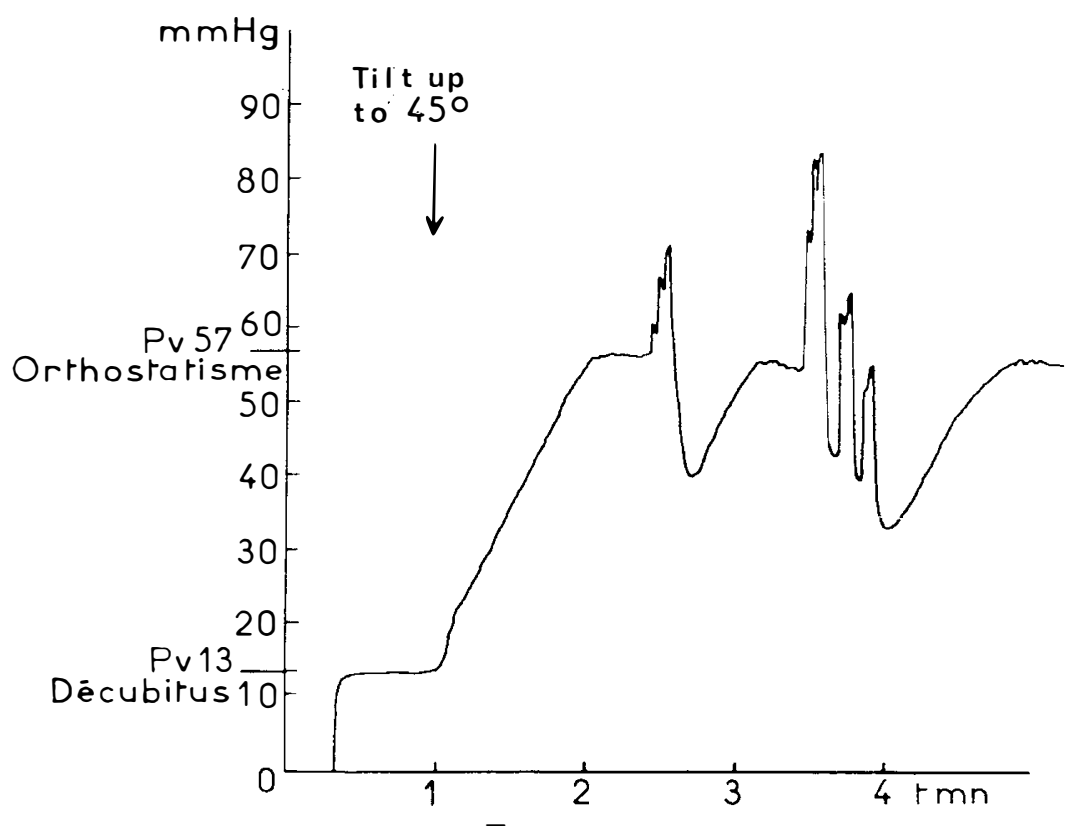

FIG. I4

Paraplegic subject: same vascular action of involuntary contractions (same I I $/ \mathbf{I}-B$ procedure as fig. I3). 
muscle relaxation and then a slow return to pre-contraction values. If the contractions are repeated, the pressure decrease is greater and the delay before reaching the resting value is longer:

\section{TABLE II}

Mean changes of venous pressure $(\Delta \mathrm{Pv})$ in the foot after muscular contractions. Results in $\mathrm{mm} . \mathrm{Hg} \pm \mathrm{I}$ S.D. $n=$ number of measurements

\begin{tabular}{|l|c|c|}
\hline Normal & $\Delta$ Pv after one contraction & $\Delta$ Pv after repeated contractions \\
\hline Paraplegics & $\begin{array}{c}19.35 \pm 2.83 \\
n=8\end{array}$ & $\begin{array}{c}28.40 \pm 6.25 \\
n=8\end{array}$ \\
\hline $\begin{array}{c}9.12 \pm 3.59 \\
n=16\end{array}$ & $\begin{array}{c}16.05 \pm 4.53 \\
n=12\end{array}$ \\
\hline
\end{tabular}

In reference to the compliance curve established in the same ambiant conditions (fig. 12) we can estimate what blood volume is sent to the heart by involuntary contractions of the legs:

After one contraction, this blood volume is $0.5 \mathrm{ml}$./100 ml.
After repeated contractions it is $0.8 \mathrm{ml}$. $/ 100 \mathrm{ml}$.

For a mean volume of 20 litres for the two lower limbs, and if the relative pressure change is the same in the whole limbs, the total blood volume sent upward may be:

IOO $\mathrm{ml}$. after one contraction

I60 $\mathrm{ml}$. after repeated contractions.

Conclusion. In spastic paraplegics, the involuntary muscular contractions of the lower limbs have the same vascular action as voluntary contractions in normal man: they decrease the venous pressure and venous blood volume in the lower limbs and greatly increase the venous return to the heart.

However, due to the differences in mechanical muscular efficiency and probably sometimes in venous integrity, this vascular action is smaller than in normal man. Furthermore, spasmodic contractions are not regular enough to ensure an excellent postural haemodynamic adaptation to tilting in the case of high spinal cord transection. But, the total loss of this extravascular action in the case of flaccid paraplegia may be important among the other factors responsible for postural hypotension.

Conclusion for the Study of Peripheral Vasomotor Adjustments to General Needs. In the infralesional area of paraplegics, vasomotor adjustments to general thermoregulation, muscular exercise and tilting are abolished. Its conservation in other general adaptations seems unlikely. And we can temporarily conclude that in the infralesional vascular area of paraplegics, the vasomotor adjustments to general needs are lost. 


\section{The Autonomic Hyperflexia}

Since the first publications by Guttmann and his co-workers (1947, 1953), this phenomenon is well known in paraplegics with spinal cord transection: this is a paroxysmal vasoconstriction in the vascular area controlled by the infralesional cord.

It is triggered by nociceptive stimulations in the infralesional area and especially in the urinary tract. Any vesical activity is associated with autonomic hyperflexia (which appears as an exaggeration of a normal vasomotor phenomenon).

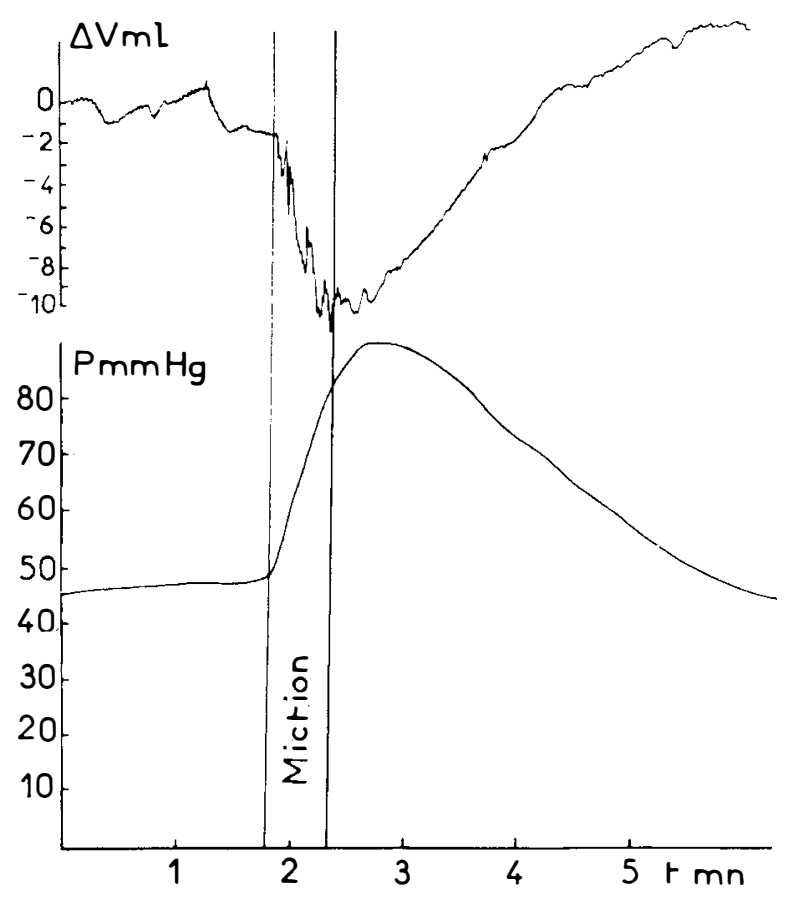

FIG. I5

Effect of an automatic micturition on the venous tone in the feet. Upper graph: decrease of the right foot volume (plethysmographic recording). Lower graph: increase of the left foot venous pressure (constant volume).

Compensatory mechanisms to the vasoconstriction appear in the normally controlled vascular area: vasodilatation and vagal bradycardia.

If the metameric level of the paraplegia is high, the constricted vascular area is large, the compensatory mechanisms are insufficient and a temporary hypertension appears. However if the metameric level is low, the compensatory mechanisms are sufficient and the autonomic hyper-reflexia may be inapparent.

During some of the vascular studies reported here automatic micturition occurred. In theses cases, the vasomotor perturbations could be registered. The perturbations affected similarly arteries and veins and were observed every time the 
studied vascular area was commanded by a non-destroyed medulla deprived of the superior nervous control.

The graphs reproduced here show the effect of autonomic hyper-reflexia upon venous tone (volume and venous pressure changes) and upon arteriolar resistance (foot blood flow changes). They were registered in a patient with a

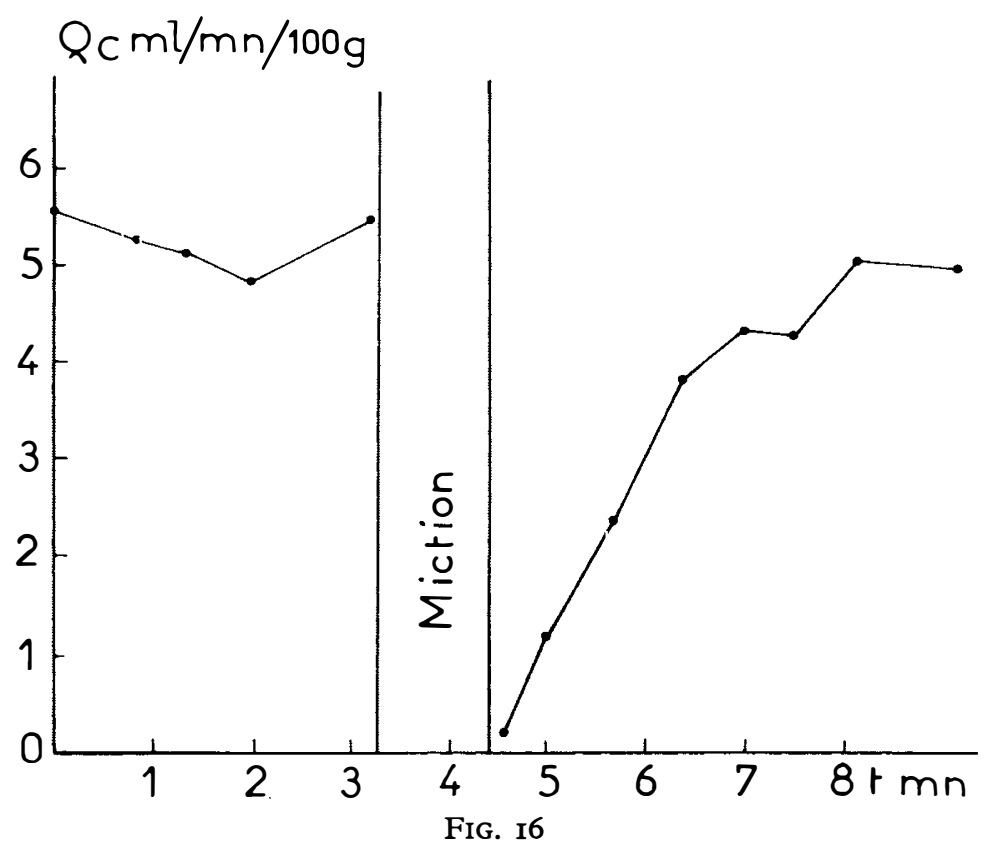

Effect of an automatic micturition on the foot blood flow (owing to involuntary muscle contractions in the lower limbs, the foot blood flow could not be measured during micturition by the plethysmographic method).

medullar transection above Tro without any clinical appearance of autonomic hyper-reflexia (figs I5-I6).

\section{GENERAL CONCLUSION}

The comportment of blood vessels deprived from central nervous control:

The vascular tone is unsteady: consequently the infralesional blood flows and blood volumes are unsteady.

The vascular tone is abnormally and directly dependent upon local and regional stimulations. A caricatural aspect of this dependance is the autonomic hyperreflexia.

Vascular adjustments to local metabolic needs are normal. lost.

But the arteriolar adjustment to local thermic needs (hunting phenomenon) is

The vascular adjustments to general needs (thermoregulation, mucular exercise, tilting) are lost.

A second kind of conclusions concern the physio-pathology of the spinal man 
and may explain some clinical observations; some of them are well known: the frequency of foot frost-bites, the usefulness of vascular compressing systems in the lower limbs and the abdomen which reduce oedema, postural hypotension and postural oliguria.

Some others are not as well known but extremely interesting, such as the relationships between circulatory comportment, orthostatism, temperature and muscular exercise. This knowledge could be very useful to the understanding of how some deficits may interact and counterbalance one another:

Orthostatism and muscular exercise are easier when ambient temperature is cool because disadaptation to cold causes a vasoconstriction which, by increasing the arteriolar resistance, increases the arterial blood pressure. The same result is obtained when a moderate sacral stimulus such as anal irritation, perineal dermatitis, colic distension, supports a light autonomic hyper-reflexia (these interactions were recently confirmed by Corbett, Frankel \& Harris, I971).

Conversely, orthostatism and muscular exercise are less tolerated when ambient temperature is warm.

In the case of high medullar transection, muscular exercise is easier in the supine position. This is a useful knowledge in rehabilitation.

Muscular contractions (especially in the abdominal wall) may be useful when they involuntarily happen during tilting: they send to the heart the blood volume of lower limbs and splanchnic area. The same result may be obtained if the increase in abdominal pressure results in stimulation of the bladder and autonomic hyperreflexia (Corbett et al., I97I). In these cases, the response to tilting may be reversed.

During this work, we made an analytic study of the vasomotor comportment and its responses to some physiological stimulations, we considered how some deficits were able to counterbalance one another and so we tried to have a general view of the cardiovascular physiology of the spinal man. We know that in some very specialised organs (such as kidney, myocardium, ....) the local circulations may have a very different comportment. However, much work must be done before knowing sufficiently the functional consequences of the loss of central nervous control upon these organs and their circulation.

\section{SUMMARY}

The vasomotor behaviour was studied comparatively in normal men and in patients with complete chronic paraplegia.

In the denervated area:

The vascular tone is variable: blood flow and blood volume are irregular.

The vascular adjustments to local metabolic needs are normal: in the cutaneous area, a temporary arrest of the circulation is followed by an important increase in blood flow. In muscular tissue, the metabolic adjustment to muscular work is ensured by an increase in local blood flow and by an increase in arteriovenous gas difference.

The cutaneous cold vasodilatation is abolished.

The vasomotor adjustments to general needs are lost: there are no vasomotor responses to the heating of the whole body or to muscular exercise of the upper limbs, or to tilting.

The vasoconstriction simultaneously occurring with bladder activity is increased: autonomic hyper-reflexia. 
A disturbance of the extravascular mechanical influences is associated to the vasomotor deficits (loss of the peripheral muscle pump).

The practical consequences of the vascular disturbances are considered. ${ }^{1}$

\section{RÉSUMÉ}

Le comportement vasomoteur a été comparativement étudié chez des sujets normaux et chez des paraplégiques par lésion médullaire compléte datant de plusieurs mois ou plusiers années.

Dans le territoire privé de controle nerveux central:

-le tonus vasculaire est instable: le débit sanguin et le volume sanguin sont variables.

- l'adaptation vasculaire aux besoins métaboliques locaux est normale: dans le territoire cutané, une interruption temporaire de la circulation est suivie d'un accroissement important du débit sanguin. Dans le tissu musculaire, l'adaptation métabolique au travail musculaire est assurée par un accroissement du débit sanguin local et de la différence artério-veineuse des gaz du sang.

- la vasodilation cutanée au froid est abolie.

-les adaptations vasculaires périphériques aux besoins généraux de l'organisme sont perdues: il n'y a pas de réponse vasomotrice au réchauffement du corps, ni à l'exercice musculaire des membres supérieurs, ni à l'orthostatisme.

-lavasoconstriction accompagnant l'activitévésicale est exagérée: c'estl'hyperreflectivité autonome bien connue.

-à ces déficits vasomoteurs est surajoutée une perturbation des influences mécaniques extra-vasculaires (perte de la pompe musculaire périphérique).

Les conséquences pratiques de ces perturbations vasculaires sont envisagées.

\section{ZUSAMMENFASSUNG}

Das vasomotorische Verhalten wurde untersucht in Patienten mit completter chronischer Paraplegie im Vergleich mit normalen Kontrollen.

Im der denervierten Gebiet ist der vaskuläre Tonus variabel: Blustrom und Blutvolumen sind irregulär.

Der vaskuläre Ausgleich zu lokalen Stoffwechsel-Bedürfnissen ist normal: Ein temporärer Arrest der Blutzirkulation im Hautgebiet wird von einem bedeutenden Anstieg des Blutstromes gefolgt. Der Stoffwechselausgleich im Muskelgewebe durch muskuläre Arbeit wird durch einen Anstieg im lokalen Blutstrom und durch Vermehrung in einer arterio-venösen Gasdifferenz gesichert.

Die Haut-Kälte Vasodilatation ist aufgehoben.

Die vasomotorischen Ausgleichungen zu allgemeinen Bedürfnissen sind verloren gegangen: Es bestehen keine vasomotorischen Reaktionen auf Erwärmung des ganzen Körpers, musculäre Anstrengung der oberen Extremitäten oder Kippen.

Die Vasokonstriktion während Blasenkontraktion ist vermehrt; autonomische Hyperreflexie.

Eine Störung des extravaskulären Einflusses ist mit dem vasomotorischen Defizit verbunden (Verlust der muskulären Muskelpumpe)

Die praktischen Konsequenzen der vaskulären Störungen werden berücksichtigt.

\section{REFERENCES}

Bargeton, D., Durand, J., Mensch-Dechene, J. \& Decaud, J. (I959). Echanges de chaleur de la main. F. Physiol. (Paris), 5I, I I I-I 50.

Benassy, J., Boissier, J. R., PAtte, D.\& Diverres, J. C. (I960). Ostéomes des paraplegiques. La Pr. Méd. 2I, 8I I-8I 4.

Bevegard, B. S. \& Shepherd, J. T. (I965). Changes in tone of limb veins during supine exercise. F. Appl. Physiol. 20, I-8.

1 Sent for publication, June 1972. 
BidART, Y. (I970). L'adaptation vasculaire à l'exercice chez les paraplegiques. Ann. Méd. Phys. 13, No. 4, 349-36r.

Bidart, Y., DuRAND, J. \& Martineaud, J. P. (I970). La vaso-dilatation cutanée paradoxale au froid. Path. Biol. 18, No. I5-I6/1 7-18, 743-747.

Bidart, Y., Durand, J. \& Martineaud, J. P. (I97I). La commande nerveuse de la veinoconstriction périphérique du début de l'exercice. Path. Biol. 19, No. I-2, I3-19.

BIDART, Y. et MAURY, M. (I97I). La vaso-motricité sous-lésionelle dans le lésions médullaires completés. Ann. Méd. Phys. 14, 3, 428-446.

Claus-Walker, J. I., Carter, R. E., Lipscomb, H. S. \& Vallbona, C. (1969). Daily rhythms of electrolytes and aldosterone excretion in man with cervical spinal cord section. F. Clin. Endocrin. 29, 300-30I.

CoOper, K. E., Ferres, H. M. \& Guttmann, L. (1957). Vasomotor responses in the foot to raising body temperature in the paraplegic patients. F. Physiol. (London), 136, 547557.

Corbett, J. L., Frankel, H. L. \& Harris, P. J. (I97I). Cardio-vascular reflexes in tetraplegia. Paraplegia, 9, 3, I I3-I 22.

Cunningham, D. J. C., Guttmann, L., Whitteridge, D. \& Wyndham, C. M. (I953). Cardiovascular-responses to bladder distention in paraplegic patients. F. Physiol. (London), I21, 58I-592.

Duff, F. (I95I). Circulatory changes in the forearm following sympathectomy. Clin. Sci. I0, 529-535.

DuFF, F. \& SHEPHERD, J. T. (I953). The circulation in the chronically denervated forearm. Clin. Sci. 12, 407-412.

Folkow, B. (1960). Role of the nervous system in the control of vascular tone. Circulation, 2I, $760-768$.

Folkow, B. \& Mellander, S. (1964). Veins and venous tone. Amer. Heart F. 68, 397408.

FREYSCHUSS, U. (1970). Cardiovascular adjustments to somatomotor activation. Acta Physiol. Scand. Supl. 342, I-63.

GALIBERT, P. (1958). Considérations anatomiques et physio-pathologiques sur les traumatismes médullaires. Thèse Lille.

Galibert, P., Fossati, P., Lopez, C., Cecille, J. P., Bonte, G., Decoulx, P. \& Laine, E. (I96I). Etude angiographique de la circulation dans les membres inférieurs aux différents stades évolutifs d'une paraplégie. Neuro-Chir. 7, No. 3, I8I-20I.

Greenfield, A. D. M. (I954). The response to cold in the range of $0-10^{\circ} \mathrm{C}$. In Peripheral Circulation in Man. Ciba Symp., I05.

Greenfield, A. D. M. (I963). Circulation through the skin. In Handbook of Physiology. Circulation II. Am. Phys. Soc. Washington.

Guttmann, L., Munro, A. F., Robinson, R. \& Walsh, J. J. (1963). Effect of tilting on the cardiovascular responses and plasma catecholamine levels in spinal man. Paraplegia, $\mathbf{I}$, 4-I 8.

GutTManN, L., Silver, J. \& Wyndham, C. H. (1958). Thermoregulation in spinal man. F. Physiol. (London), 142, 406-4I 9.

GutTMANN, L. \& WhitTERIDGE, D. (I947). Effects of bladder distension on automatic mechanisms after spinal chord injuries. The Brain, 70, 36I-375.

HADDY, F. J. \& ScotT, J. B. (I968). Metabolically linked vasoactive chemicals in local regulation of blood flow. Phys. Rev. 48, No. 4, 688-707.

HermanN, H. (1936). La vie sans moëlle épinière. Biol. Méd. 26, 5, 252-325.

HermanN, H., MORIN, G. \& CiER, J. (I937). Activités vasotoniques des ganglions de la chaine sympathique. Ann. Physiol. et Phys. Chim. Biol. 13, 2, 316-340.

Jaeger-Denavit, O., Gaussel, J., Bedoiseau, M., Pannier, S., Lacert, P. \& Grossiord, A. (1969). Vaso-motricité cutanée chez les paraplégiques. Pr. Méd. 77, No. 35, I207I209.

Johnson, R. H. (I97I). Temperature regulation in paraplegia. Paraplegia, 9, No. 3, I 37-I 45 .

Johnson, R. H., PARK, D. M. \& Frankei, H. L. (I97I). Orthostatic hypotension and reninangiotensin system in paraplegia. Paraplegia, 9, No. 3, I46-I 52.

Lassen, N. A., LindbJeRG, I. F. \& MUNCK, O. (I964). Measurement of blood-flow through skeletal muscle by intramuscular injection of Xenon I33. Lancet, I, 686-688. 
Martineaud, J. P., Verpillat, J. M., Pavilion, N., Roudy, G. \& Seroussi, S. (I970). Comportement des vaisseaux capacitifs de la main lors d'un exercice bref et modéré des membres inférieurs. F. Physiol. (Paris), 62, Suppl. I, I87.

MAURY, M. (1966). Des manifestations neuro-vegétatives dans les lésions médullaires. Pr. Méd. 74, No. 32, 1673-1678.

Miller, J. M., DownEY, J. A. \& DARLING, R. C. (1969). Thermal regulation in spinal man. Proc. of the I7th Veterans Adm. Spinal Cord Injury Conf. I IO-I I6.

RANDAlL, W.C., Wurster, R. D. \& LEWIN, R. L. (I966). Response of patients with high spinal transsection to high ambient temperature. F. Appl. Physiol. 21, 983-993.

SAMUELOFF, S. L., BROWSE, N. L. \& SHEPHERD, J. T. (I966). Response of capacity vessels in human limbs to head-up tilt and suction on lower body. F. Appl. Physiol. 21, 47-54.

SAmueloff, S. L., Bevegard, N. S. \& Shepherd, J. T. (I966). Temporary arrest of the circulation to a limb for the study of venomotor reactions in man. F. Appl. Physiol. 21, 34I-346.

Seroussi, S., Martineaud, J. P., Verpillat, J. M. \& Durand, J. (1967). Résistance et capacitance vasculaires cutanées chez l'homme à voies nerveuses normales ou interrompues. F. Physiol. (Paris), 59, 502-503.

Seroussi, S., Verpillat, J. M., Roudy, G. \& Martineaud, J. P. (I969). Participation du débit sanguin cutané de la main à l'a daptation circulatoire lors d'un exercice des membres inférieurs. F. Physiol. (Paris), 61, Suppl. 2, 403-404.

SHEPHERD, J. T. (1964). Reactive hyperemia in human extremities. Circ. Res. 15, Suppl. I, 76-78.

ShePherd, J. T. \& Thomson, I. D. (1953). The response to cold of the blood vessels of denervated fingers during the regeneration of the nerves. Irish f. Med. Sci. 329, 2082 II.

SILVER, J. R. (1965). Circulatory reflexes in spinal man. Paraplegia, 2 , No. 4, 235-246.

Wallace, J. M. \& DuRhaM, N. C. (1956). Pressure relationships among arteries and large and small veins. Circulation, 14, I013-1014.

Whitney, R. J. (I953). The measurement of volume changes in human limbs. F. Physiol. (London), 121, I-27. 